\title{
Perangkat Lunak Pengelolaan Surat Di Kecamatan Lengkong
}

\author{
Deden Sofyan Hamdani \\ Program Studi Sistem Informasi STMIK LPKIA \\ Jl. Soekarno Hatta No. 456 Bandung 40266, Telp. +62 2275642823 , Fax. +62 227564282 \\ e-mail: deanhamdani@lpkia.ac.id
}

\begin{abstract}
Abstrak
Perkembangan teknologi saat ini membuat membuat informasi yang dibutuhkan semakin mudah untuk didapatkan, hal ini dapat dilihat dari meningkatnya dan berkembangnya kebutuhan masyarakat, perusahaan, dan juga instansi pemerintahan dalam mendapatkan data dan informasi. Kantor Kecamatan Lengkong Kota Bandung merupakan salah satu instansi pemerintahan dalam mengelola surat masih menggunakan buku pencatatan (agenda). Kantor Kecamatan Lengkong Kota Bandung membutuhkan Perangkat Lunak Pengelolaan Surat yang dapat melakukan pengolahan dan penyampaian informasi datadata surat. Untuk merancang perangkat lunak berbasis desktop, maka diperlukan tahapan perancangan dengan menggunakan metode prototype dengan tahapan-tahapan: komunikasi, perencanaan secara cepat, pemodelan perancangan secara cepat, pembentukan prototyping, dan penggunaan sistem, serta tools untuk merancang perangkat lunak berbasis desktop menggunakan Star UML. Bahasa pemograman untuk membuat desktop dengan menggunakan bahasa pemograman Visual Basic, dan database-nya MySQL.
\end{abstract}

Kata Kunci: Informasi, Berbasis Desktop, Surat

\section{The Letters Management Software at Lengkong District}

\begin{abstract}
Current technological developments make required information easier to obtain; this can be seen from the increasing and developing needs of the community, companies and government agencies in obtaining data and information. Lengkong District Office, Bandung City, is one of the government agencies that still uses a record book (agenda) in managing letters. Lengkong District Office, Bandung City, needs a Letter Management Software that can process and deliver information on letters'data. To design a desktop-based software, a designing stage is required using a prototype metohe having stages as follows: communication, rapid planning, rapid design modeling, prototyping, and system usage, as well as tools for designing a desktop-based software using Star UML. The programming language to create a desktop uses the Visual Basic programming language, and the database is MYSQL.
\end{abstract}

Keywords: Information, Desktop Based, Letter

\section{Pendahuluan}

Pengelolaan surat merupakan hal yang penting bagi sebuah organisasi. Surat merupakan salah satu sarana atau media yang digunakan oleh manusia di dalam melakukan komunikasi secara tertulis. Surat dibedakan ke dalam dua golongan yaitu surat pribadi dan surat resmi. Surat pribadi adalah surat yang ditunjukan dari seseorang kepada orang lain dan bersifat tidak resmi, sedangkan surat resmi adalah surat yang ditunjukan dari suatu instansi atau perusahaan kepada instansi lainnya dan bersifat resmi. Pembuatan surat resmi biasanya menggunakan kop surat dan dicantumkan nomor surat, perihal, dan stempel agar lebih resmi. 
Beberapa faktor penentuan kualitas informasi Informasi yang dibutuhkan harus akurat, tepat waktu, dan relevan. Semakin tinggi kualitas informasi yang dihasilkan, maka kepuasan pelanggan semakin meningkat [1] [2]. Pendapat ini telah dibahas dalam penelitian sebelumnya oleh Kim dan McHaney [3].

Setiap organisasi dapat dipastikan mempunyai suatu unit khusus yang bertugas dalam bidang administrasi yang mengelola segala suatu yang berhubungan dengan kegiatan administrasi yang pada akhirnya akan berhubungan dengan kegiatan kearipan. Kegiatan administrasi pada dasarnya adalah menghasilkan, menerima, mengolah, dan menyimpan berbagai surat, laporan, formulir, dan sebagainya.

Dengan alasan tersebut maka pada masa sekarang banyak organisasi atau instansi yang menggunakan media elektronik dalam pengelolaan arsip, mulai dari model tradisional tidak menggunakan database sampai yang menggunakan media canggih/digital. Pada Kantor Kecamatan Lengkong, pengelolaan arsip surat masih belum menggunakan komputerisasi tetapi masih secara pencatatan dalam bentuk sebuah buku pencatatan dan pengarsipannya, sehingga dalam proses pencarian, penyimpanan dan pengolahan masih memerlukan waktu, dan pemberitahuan surat kepada atasan juga sering terlambat.

\section{Tinjauan Pustaka}

\section{Surat}

Surat sebagai sarana komunikasi dalam menyampaikan informasi tertulis dari suatu pihak kepada pihak yang lain, di mana surat berfungsi untuk sarana pemberitahuan, permintaan, buah pikiran gagasan, alat bukti tertulis, alat pengingat, bukti historis, dan pedoman kerja [4].

\section{Prototyping}

Penelitian yang digunakan pada perancangan lunak pengelolaan surat ini adalah metode prototyping. Pembuatan prototyping diawali dengan adanya komunikasi di antara tim pengembang perangkat lunak dengan pelanggan. Melakukan beberapa pertemuan di antara tim pengembang perangkat lunak dengan para stakeholder yang bertujuan untuk medapatkan sasaran keseluruhan terhadap perangkat lunak yang akan dikembangkan, melakukan identifikasi terhadap spesifikasi kebutuhan yang berhubungan dengan sistem berjalan, dan melakukan penggambaran terhadap area - area di mana definisi yang lebih jauh. Perencanaan pembuatan prototyping dilakukan dengan cepat dan melakukan pemodelan. Pengguna akhir akan melihat representasi semua aspek perangkat lunak, misalnya rancangan antarmuka. Para stakeholder menerima prototyping, kemudian mereka akan melakukan evaluasi terhadap prototyping yang sudah dibuatkan sebelumnya, dan memberikan umpan-balik yang bertujuan untuk memperhalus spesifikasi kebutuhan. Melakukan perbaikan terhadap prototyping agar kebutuhan dari para stakeholder terpenuhi. [5]

Tahapan-tahapan dari prototyping yaitu:

1 Komunikasi: merupakan tahapan peneliti melakukan komunikasi dengan pegawai Kecamatan lengkong untuk melakukan pendefinisian kebutuhan perangkat lunak dan pendefinisian garis besar sistem yang akan dibuat.

2 Perencanaan secara cepat: merupakan tahapan perencanaan yang akan dilakukan oleh penelitian berdasarkan data yang dikumpulkan sebelumnya.

3 Pemodelan Perancangan secara cepat: merupakan tahapan kumpulan dari nilai-nilai, prinsip, dan praktik dalam menerapkan model perangkat lunak terhadap proyek pengembangan perangkat lunak secara efektif dan secara ringan

4 Pembentukan Prototyping: Pembentukan prototyping dilakukan oleh pelanggan apakah prototyping yang sudah dibangun sudah sesuai dengan keinginan dari pelanggan. Apabila prototyping belum sesuai, maka dilakukan perbaikan dengan mengulang langkah sebelumnya. Jika prototyping sesuai, maka aplikasi siap untuk digunakan.

5 Penggunaan Sistem: Pelanggan menerima perangkat lunak yang sudah diuji dan siap untuk digunakan. 
Perangkat Lunak Pengelolaan Surat Di Kecamatan Lengkong

\section{Object Oriented Programming}

Object oriented programming (OOP) merupakan suatu pendekatan pembuatan program yang menggunakan object dan class. Beberapa keuntungan dari OOP yaitu Reusability, Extensibility, dan Maintainability [6]

\section{Unified Modeling Language (UML)}

Unified Modeling Language (UML) merupakan bahasa pemodelan untuk sistem atau perangkat lunak yang berparadigma berorientasi objek [7]

Jenis - jenis diagram Unified Modeling Language (UML) :

1. Diagram Usecase (Use Case Diagram)

Bersifat status. Diagram ini memperlihatkan himpunan use-case dan aktor (suatu jenis khusus dari kelas). Diagram ini terutama sangat penting untuk mengorganisasi dan memodelkan perilaku suatu sistem yang dibutuhkan serta diharapkan pengguna.

2. Diagram Aktivitas (Activity Diagram)

Bersifat dinamis. Diagram aktivitas adalah tipe khusus dari diagram status yang mempelihatkan aliran dari suatu aktivitas ke aktivitas lainnya dalam suatu sistem. Diagram ini terutama penting dalam pemodelan fungsi-fungsi suatu sistem dan memberi tekanan pada aliran kendali antar objek.

3. Diagram Kelas (Class Diagram)

Bersifat statis. Diagram ini memperlihatkan himpunan kelas-kelas antarmuka-antarmuka, kolaborasikolaborasi, serta relasi-relasi. Diagram ini umum dijumpai pada pemodelan sistem berorientasi objek. Meskipun bersifat statis, sering pula digaram kelas memuat kelas-kelas aktif.

\section{Diagram Sequence (Sequence Diagram)}

Bersifat dinamis. Sequence diagram yaitu salah satu jenis diagram pada UML yang menjelaskan interaksi objekyang berdasarkan urutan waktu, sequence diagram juga dapat menggambarkan urutan atau tahapan yang harus dilakukan untuk dapat menghasilkan sesuatu seperti pada use case diagram.

\section{Black Box}

Pengujian Black Box berfokus terhadap spesifikasi fungsional dari perangkat lunak. Penguji dapat memberikan definisi tentang kumpulan kondisi input dan melakukan pengujian terhadap spesifikasi fungsional program [8].

Pengujian Black Box untuk menemukan kesalahan pada kategori:

1. Fungsi yang hilang atau fungsi tidak benar.

2. Kesalahan terhadap antarmuka.

3. Kesalahan terhadap struktur data atau akses database eksternal

4. Inisialisasi dan pemutusan kesalahan. 


\section{Analisis dan Perancangan \\ Use Case Diagram}

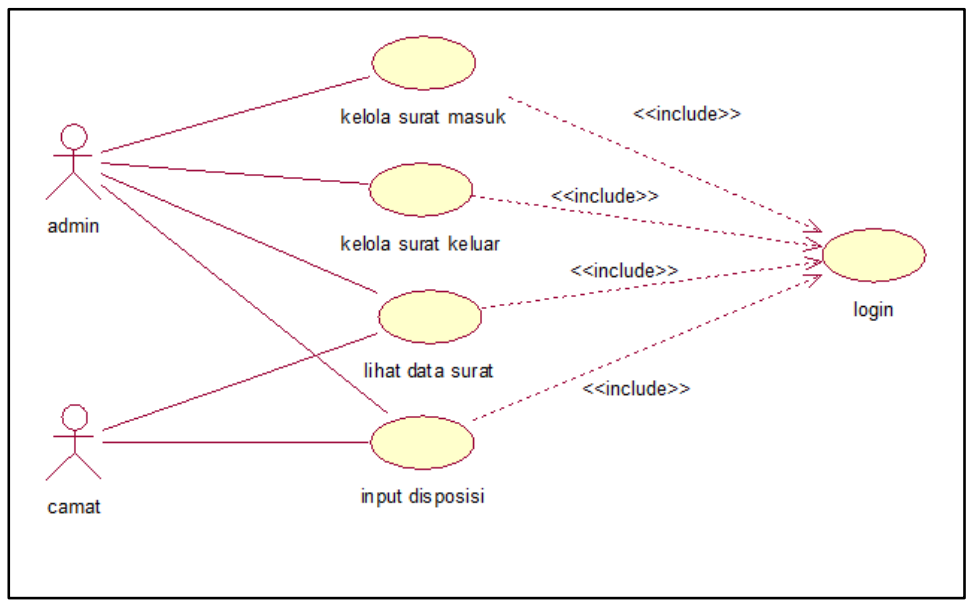

Gambar 1 Use Case Diagram

Tabel 1 Use Case Scenario Kelola Surat masuk

\begin{tabular}{|l|l|}
\hline \multicolumn{2}{|c|}{ Use Case Skenario untuk Melakukan kelola surat } \\
masuk
\end{tabular}

Tabel 2 Use Case Skenario Kelola Surat Keluar

\begin{tabular}{|c|c|}
\hline \multicolumn{2}{|c|}{ Use Case Skenario untuk Melakukan Login } \\
\hline Nama Use Case & Input Surat Keluar \\
\hline Deskripsi & $\begin{array}{l}\text { Digunakan untuk } \\
\text { menginputkan surat keluar }\end{array}$ \\
\hline Aktor & KSB umpeg \\
\hline Kondisi Awal & Menampilkan halaman utama \\
\hline Kondisi akhir & Menampilkan list surat keluar \\
\hline \multicolumn{2}{|c|}{ Skenario } \\
\hline Aksi Aktor & Reaksi Sistem \\
\hline \multicolumn{2}{|l|}{ 1. Klik menu surat keluar } \\
\hline & $\begin{array}{ll}\text { 2. Menampilkan menu } \\
\text { surat keluar }\end{array}$ \\
\hline $\begin{array}{l}\text { 3. Menginputkan } \\
\text { kepada, perihal dan } \\
\text { file surat }\end{array}$ & \\
\hline \multicolumn{2}{|l|}{ 4. Klik tombol simpan } \\
\hline & $\begin{array}{l}\text { 5. Menampilkan list surat } \\
\text { keluar }\end{array}$ \\
\hline \multicolumn{2}{|c|}{ Exceptional Case } \\
\hline $\begin{array}{l}\text { Jika data surat yang di input } \\
\text { tidak sesuai dengan format a } \\
\text { maka data tidak dapat disim }\end{array}$ & $\begin{array}{l}\text { an pada form input surat keluar } \\
\text { an format tidak diisi sesuai form } \\
\text { an memberikan pesan eror }\end{array}$ \\
\hline
\end{tabular}


Tabel 3 Use Case Skenario Input Disposisi

\begin{tabular}{|c|c|}
\hline \multicolumn{2}{|c|}{ Use Case Skenario untuk Melakukan Login } \\
\hline Nama Use Case & Input disposisi \\
\hline Deskripsi & $\begin{array}{l}\text { Digunakan memberikan } \\
\text { disposisi surat masuk }\end{array}$ \\
\hline Aktor & KSB umpeg \\
\hline Kondisi Awal & Menampilkan halaman utama \\
\hline Kondisi akhir & $\begin{array}{l}\text { Mengirim disposisi dan } \\
\text { menampilkan list surat masuk }\end{array}$ \\
\hline \multicolumn{2}{|c|}{ Skenario } \\
\hline Aksi Aktor & Reaksi Sistem \\
\hline \multicolumn{2}{|l|}{ 1. Masuk ke menu surat masuk } \\
\hline & $\begin{array}{l}\text { 2. Menampilkan form menu } \\
\text { surat masuk }\end{array}$ \\
\hline \multicolumn{2}{|l|}{ 3. Memilih file surat masuk } \\
\hline & $\begin{array}{l}\text { 4. Menampillkan file surat } \\
\text { masuk yang dipilih }\end{array}$ \\
\hline \multicolumn{2}{|l|}{ 5. Mengklik tombol disposisi } \\
\hline & $\begin{array}{l}\text { 6. Menampillkan modul } \\
\text { disposisi }\end{array}$ \\
\hline \multirow[t]{2}{*}{$\begin{array}{l}\text { 7. Menginputkan uraian perintah } \\
\text { untuk surat masuk dan klik } \\
\text { tombol simpan }\end{array}$} & \\
\hline & $\begin{array}{l}\text { 8. Menyimpan disposisi dan } \\
\text { menampilkan list surat } \\
\text { masuk }\end{array}$ \\
\hline \multicolumn{2}{|c|}{\begin{tabular}{|l} 
Exceptional Case \\
\end{tabular}} \\
\hline \multicolumn{2}{|c|}{$\begin{array}{l}\text { Jika informasi tidak diisi maka data tidak dapat disimpan dan memberikan } \\
\text { pesan eror }\end{array}$} \\
\hline
\end{tabular}

\section{Class Diagram}

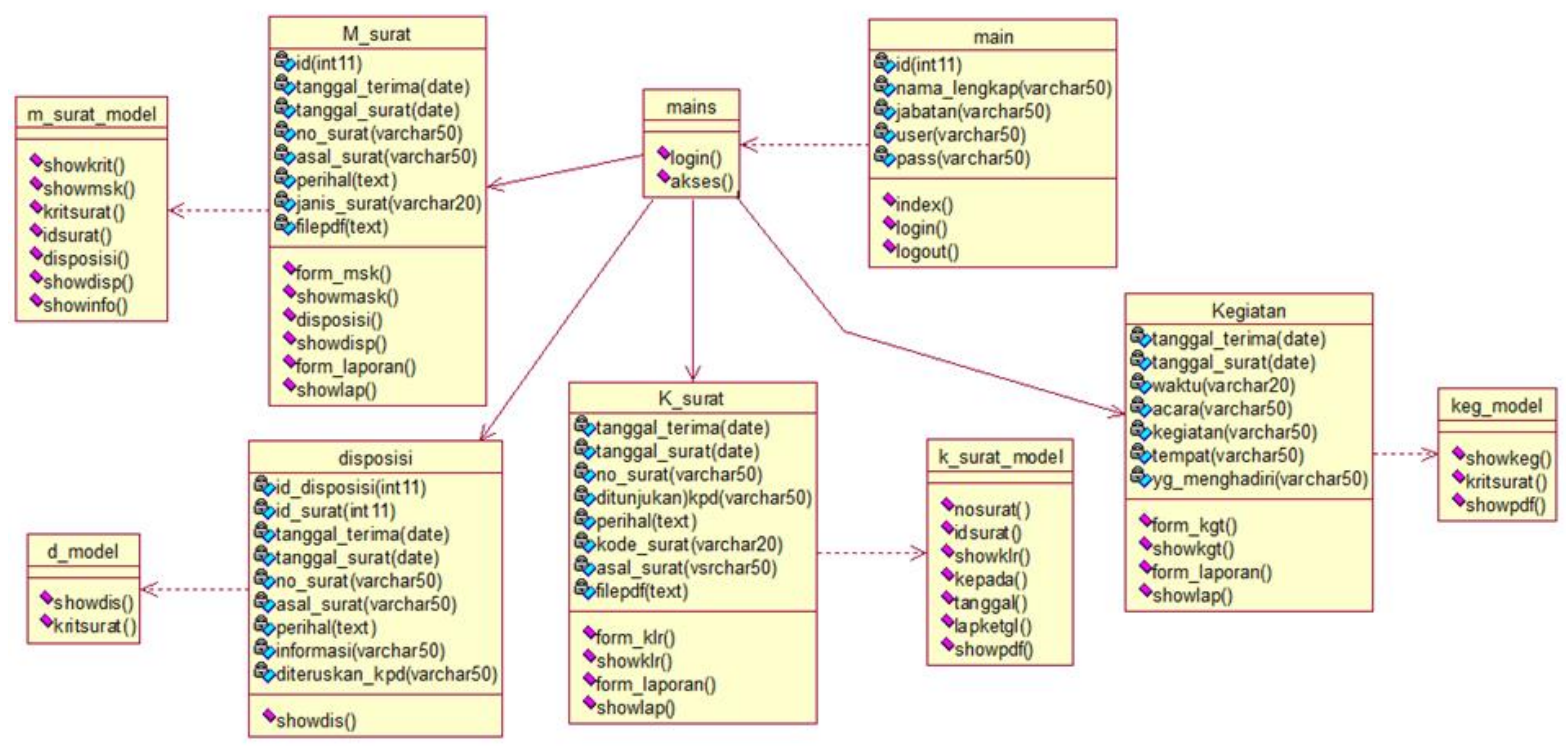

Gambar 2 Class Diagram 


\section{Activity Diagram}

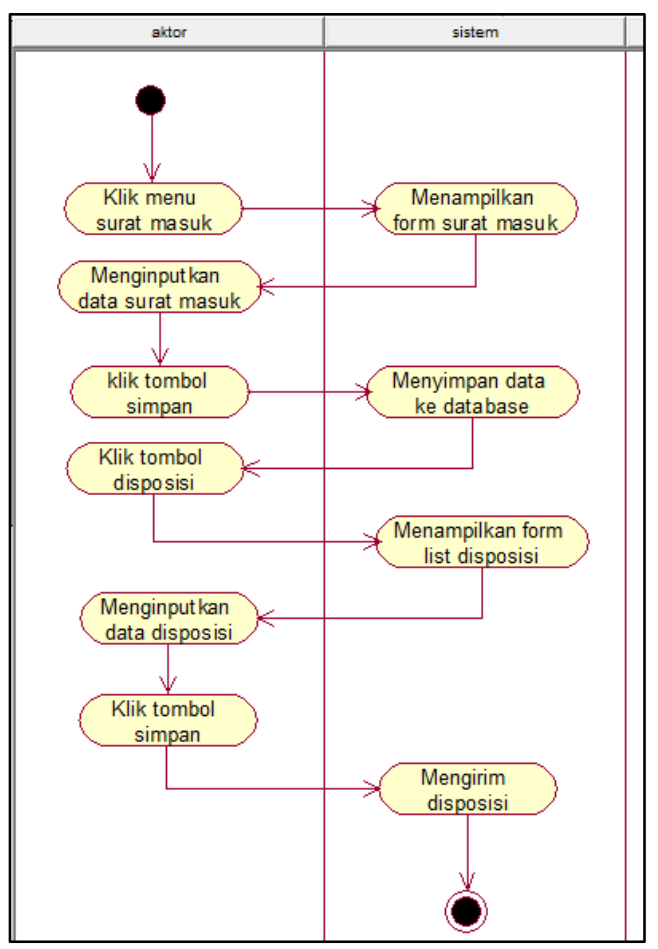

Gambar 3 Activity Diagram Kelola Surat Masuk

\section{Perancangan Antar Muka}

\section{Halaman Kelola Surat Masuk}

Fungsi : Untuk menginputkan data surat masuk

Bentuk :

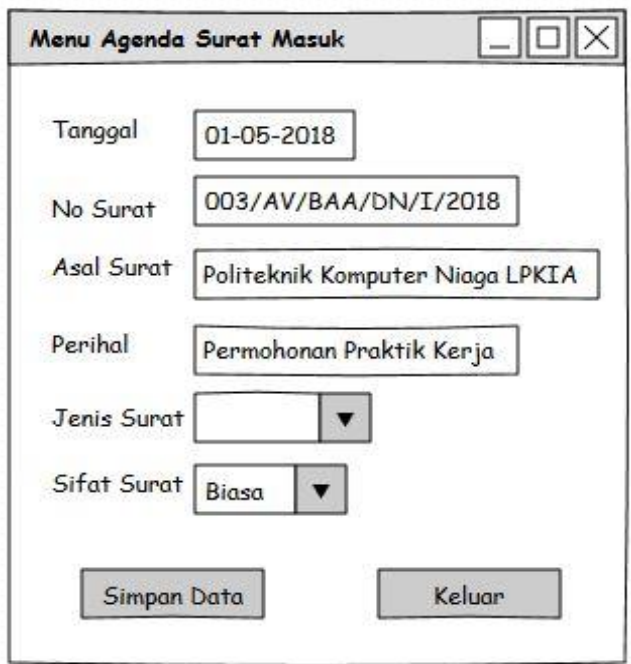

Gambar 5 Rancang Halaman Agenda Surat Masuk

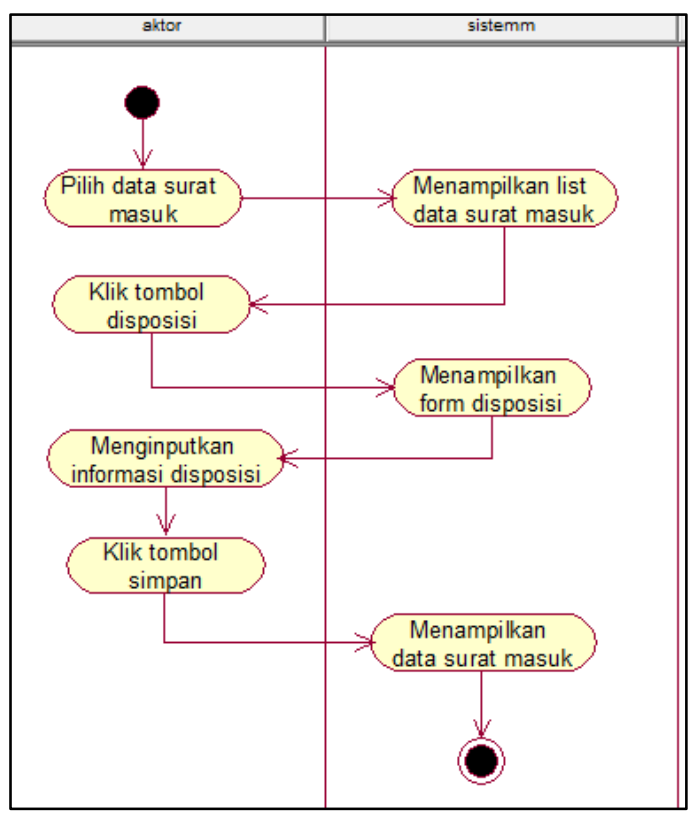

Gambar 4 Activity Diagram Input Disposisi

\section{Halaman Kelola Surat Keluar}

Fungsi : untuk menginputkan data surat keluar

Bentuk :

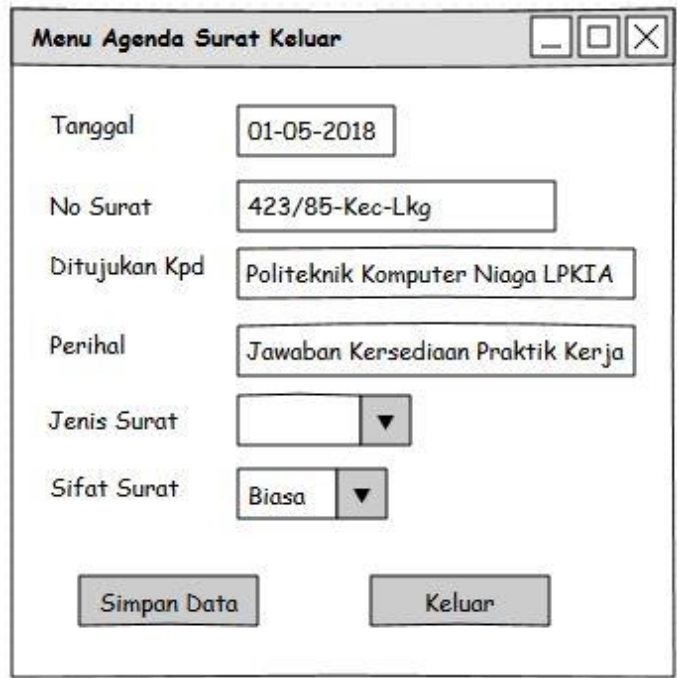

Gambar 6 Halaman Agenda Surat Keluar 


\section{Hasil}

\section{Halaman Muka}

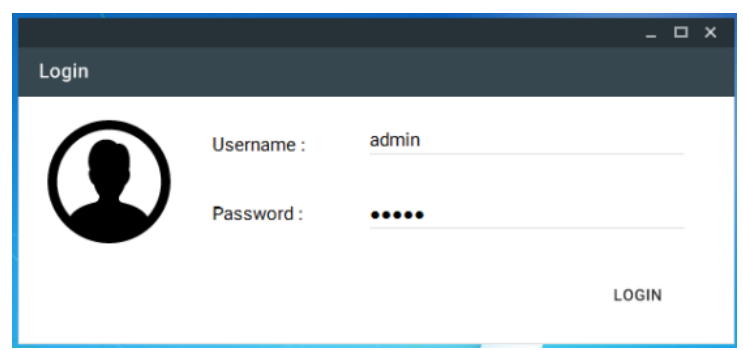

Gambar 7 Dialog Screen Login

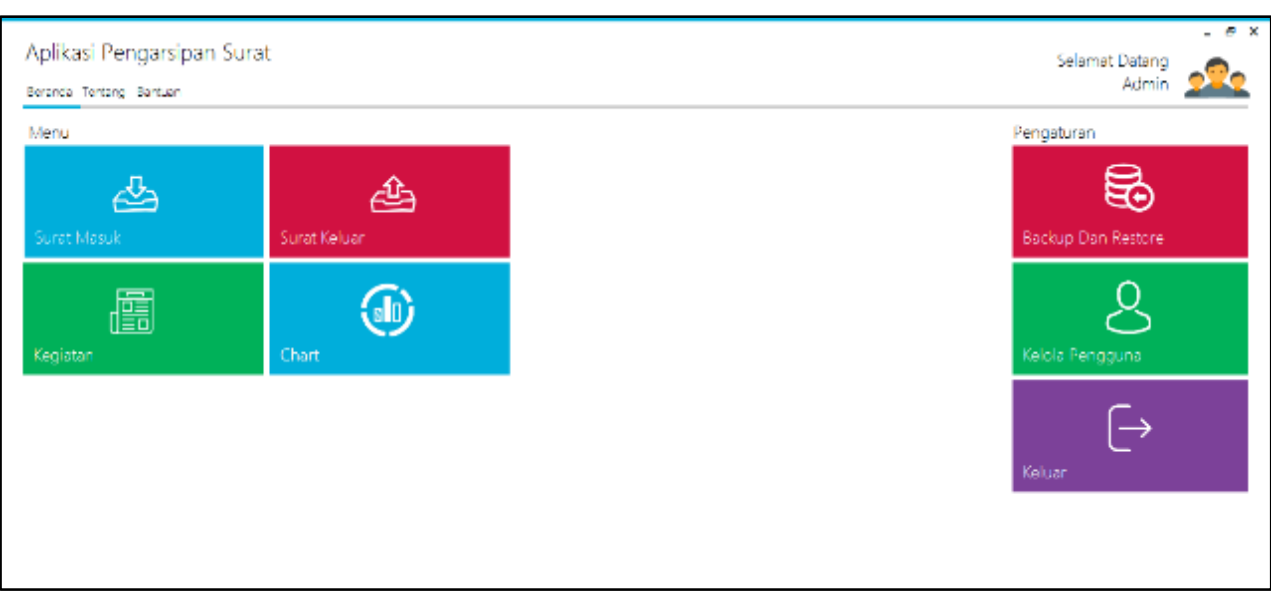

Gambar 8 Dialog Screen Beranda

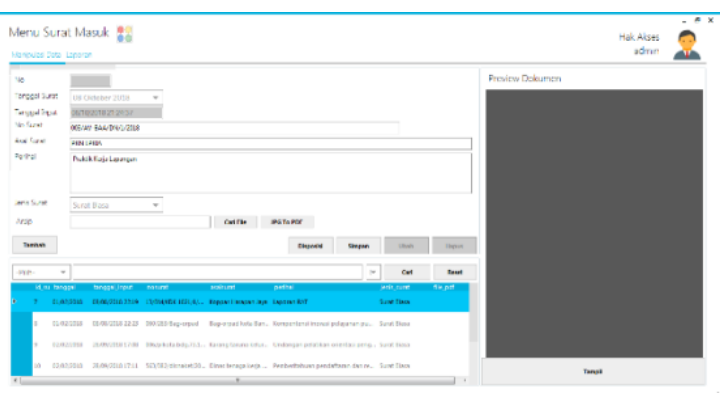

Gambar 9 Dialog Screen Menu Surat Masuk

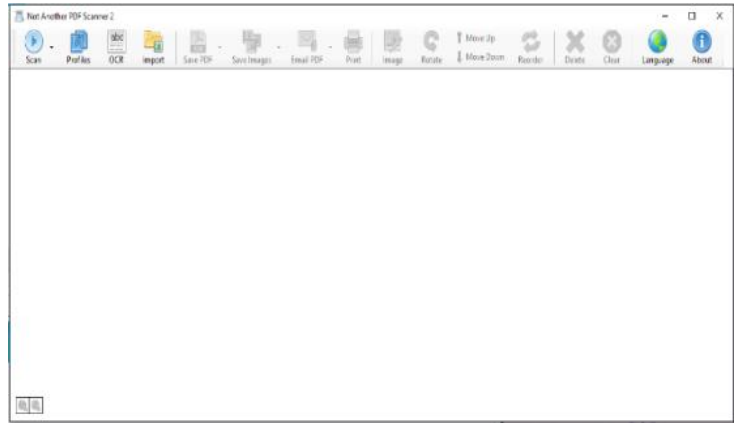

Gambar 10 Form Menu Scan Surat Masuk 


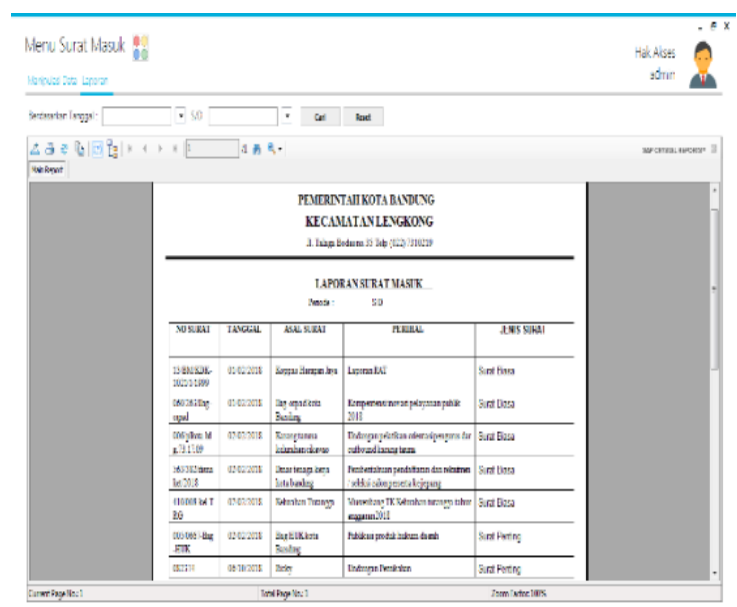

Gambar 11 Form Menu Surat Masuk

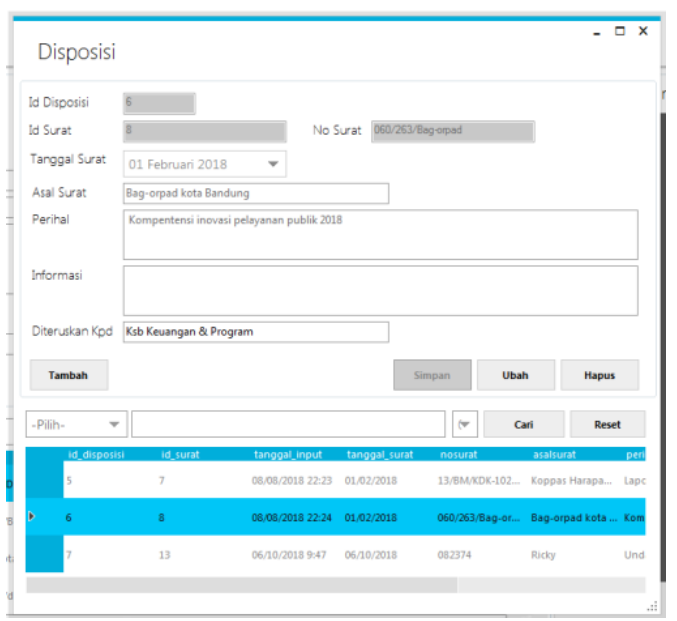

Gambar 12 Menu Disposisi

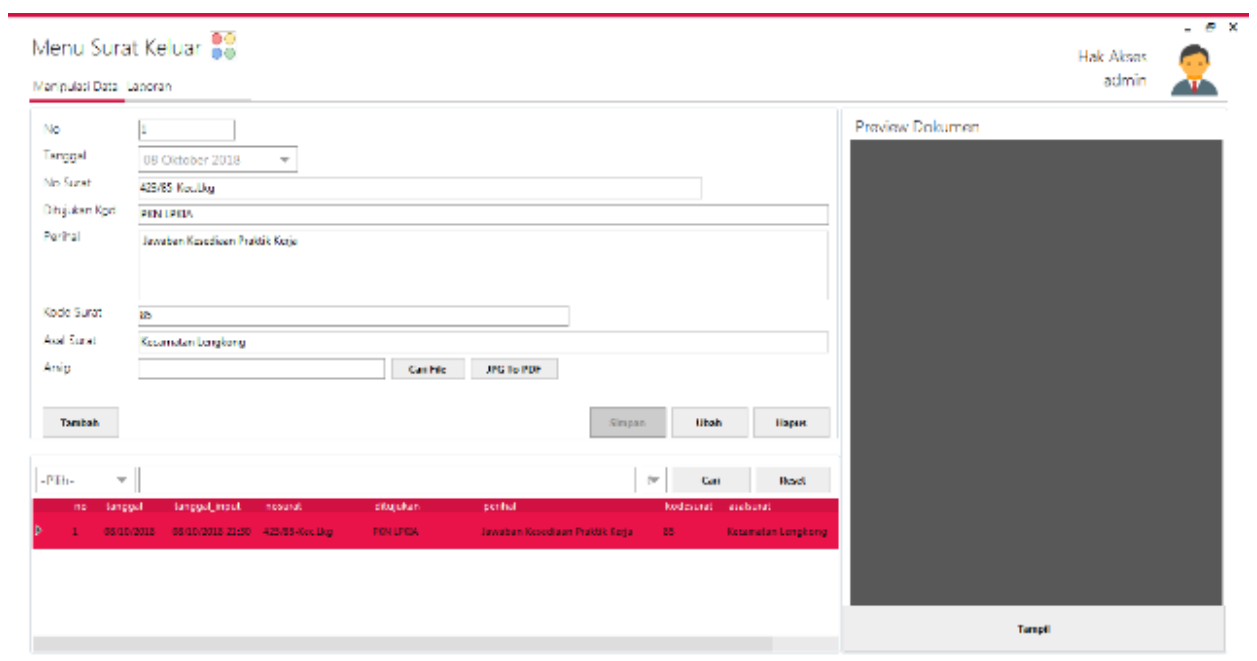

Gambar 13 Menu Surat Keluar

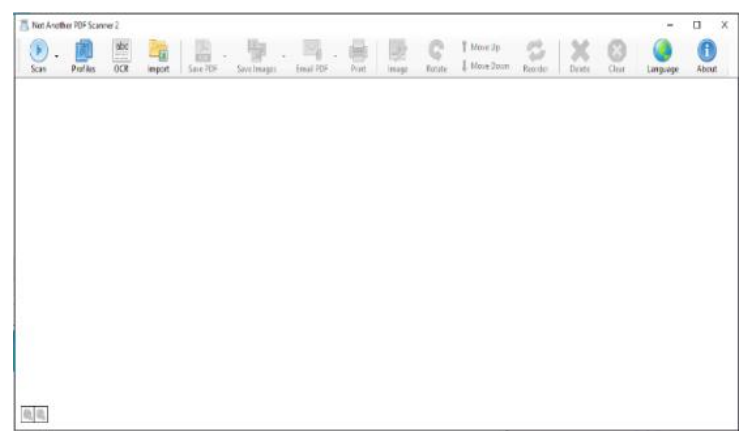

Gambar 14 Form Menu Scan Surat Keluar

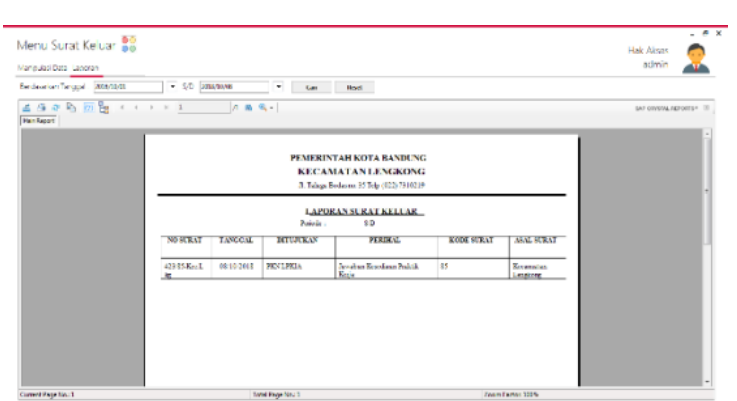

Gambar 15 Form Menu Surat Keluar 


\section{Pengujian}

Pengujian yang digunakan untuk menguji aplikasi ini adalah metode pengujian black box. Pengujian balck box berfokus pada persyaratan fungsional perangkat lunak.

Tabel 4 Hasil pengujian

\begin{tabular}{|c|c|l|l|c|}
\hline No. & $\begin{array}{c}\text { Fungsi yang } \\
\text { di uji }\end{array}$ & \multicolumn{1}{|c|}{ Cara Pengujian } & \multicolumn{1}{|l|}{ Hasil yang di harapkan } & $\begin{array}{c}\text { Hasil } \\
\text { Pengujian }\end{array}$ \\
\hline 1. & $\begin{array}{c}\text { Validasi } \\
\text { Login }\end{array}$ & $\begin{array}{l}\text { Mengisi username dan } \\
\text { password dengan benar } \\
\text { lalu klik tombol login }\end{array}$ & $\begin{array}{l}\text { Sistem menerima akses } \\
\text { login dan masuk ke halaman } \\
\text { beranda }\end{array}$ & $\checkmark$ \\
\hline 2. & $\begin{array}{c}\text { Validasi } \\
\text { Login }\end{array}$ & $\begin{array}{l}\text { Mengisi username dan } \\
\text { password dengan data } \\
\text { yang salah lalu klik } \\
\text { tombol login }\end{array}$ & $\begin{array}{l}\text { Sistem akan menolak akses } \\
\text { login dan sistem akan } \\
\text { menghapus isi field } \\
\text { password kolom }\end{array}$ & $\checkmark$ \\
\hline 3. & $\begin{array}{l}\text { Valistem akan menampilkan } \\
\text { Pencarian } \\
\text { data sesuai kata kunci yang } \\
\text { dicari }\end{array}$ & $\begin{array}{l}\text { Mengisi dencarian dengan kati } \\
\text { kunci data yang telaah } \\
\text { ada lalu klik tombol } \\
\text { pencarian }\end{array}$ & $\checkmark$ \\
\hline 4. & $\begin{array}{c}\text { Validasi } \\
\text { Tambah Surat } \\
\text { Baru }\end{array}$ & $\begin{array}{l}\text { Mengisi data surat (data } \\
\text { yang dinput lengkap), } \\
\text { lalu klik tombol simpan }\end{array}$ & $\begin{array}{l}\text { Sistem akan menyimpan } \\
\text { data surat dan akan } \\
\text { menampilkan pada tabel }\end{array}$ & $\checkmark$ \\
\hline 5. & $\begin{array}{c}\text { Validasi Ubah } \\
\text { Melakukan ubah data } \\
\text { surat lalu klik tombol } \\
\text { simpan }\end{array}$ & $\begin{array}{l}\text { Sistem akan menyimpan } \\
\text { perubahan data surat dan } \\
\text { akan menampilkan pada } \\
\text { tabel }\end{array}$ & $\checkmark$ \\
\hline 6. & $\begin{array}{l}\text { Validasi } \\
\text { Hapus }\end{array}$ & $\begin{array}{l}\text { Melakukan hapus data } \\
\text { surat dengan klik tombol } \\
\text { hapus }\end{array}$ & $\begin{array}{l}\text { Sistem akan menghapus data } \\
\text { surat yang dipilih dan tidak } \\
\text { menampilkan lagi dalam list } \\
\text { data surat }\end{array}$ & $\checkmark$ \\
\hline
\end{tabular}

\section{Pembahasan/Kesimpulan}

Pada penelitian ini dilakukan perancangan perangkat lunak Pengelolaan Surat di Kecamatan Lengkong, perangkat lunak ini untuk menggantikan pengelolaan surat yang hanya dicatat pada buku pencatatan atau agenda. Perangkat lunak ini dirancang untuk menyediakan laporan pengelolaan surat baik itu surat masuk maupun surat keluar. Adapun untuk pengembangan ke depan ditambahkan beberapa fitur-fitur lain yang dapat menjadikan perangkat lunak pengelolaan surat ini menjadi lebih baik dan lengkap.

\section{Daftar Pustaka}

[1]. Jogiyanto, HM., Analisis \& Desain Sistem Informasi: Pendekatan Terstruktur, Teori, dan Aplikasi Bisnis, Edisi Ketiga, Yogyakarta: Andi, 2005.

[2]. DeLone, W.H., and Ephraim R. Mclean. 1992, "Information System Success: The Quest for the Dependent Variable", Information System Research, March, 60-95.

[3]. Kim, S., McHaney, R. 2000. "Validation of the end-user computing satisfaction instrument in case tool environments", Journal of Computer Information Systems, 41(1), pp. 49-56

[4]. Vironica, Arie, et al., "Rancangan Bangun Aplikasi Pengelolaan Surat Masuk dan Surat Keluar Pada Sekolah Menengah Pertama Negeri 2 Nawangan", Speed-Sentra Penelitian Engineering dan Edukasi, 2013.

[5]. R. S. Pressman, Software engineering: a practitioner's approach, Palgrave Macmillan, 2005.

[6]. Ramadhani C, Dasar Algoritma \& Struktur Data dengan Bahasa JAVA, 1e. Yogyakarta: Andi Offset, 2015.

[7]. Adi Nugroho, Rekayasa Perangkat Lunak Berbasis Objek dengan Metode USDP. Yogjakarta. Andi, 2010 
[8]. Mustaqbal, M. Sidi, Firdaus, Roeri Fajri, Rahmadi, Hendra, Pengujian Aplikasi Menggunakan Black Box Testing Boundary Value Analysis (Studi Kasus: Aplikasi Prediksi Kelulusan SMNPTN), Jurnal Teknologi Informasi Terapan, 2016. 